\title{
Qualitative and Quantitative Feasibility of Biogas Production from Kitchen Waste
}

\author{
Haftu Gebretsadik, Solomon Mulaw, Giday Gebregziabher
}

Department of Chemistry, Debre Berhan University, Debre Berhan, Ethiopia

\section{Email address:}

hgebretsadik4@gmail.com (H. Gebretsadik)

\section{To cite this article:}

Haftu Gebretsadik, Solomon Mulaw, Giday Gebregziabher. Qualitative and Quantitative Feasibility of Biogas Production from Kitchen Waste. American Journal of Energy Engineering. Vol. 6, No. 1, 2018, pp. 1-5. doi: 10.11648/j.ajee.20180601.11

Received: September 10, 2017; Accepted: December 28, 2017; Published: March 7, 2018

\begin{abstract}
This study focuses on production of biogas from kitchen waste using modified digester. The digester has been placed in four different conditions. As the result shows, production of gas gradually increased and peaked to $0.360,0.260$, 0.150 and $0.116 \mathrm{~m}^{3}$ at $9^{\text {th }}, 12^{\text {th }}, 17^{\text {th }}$ and $23^{\text {th }}$ days of the $1^{\text {st }}, 2^{\text {nd }}, 3^{\text {rd }}$ and $4^{\text {th }}$ sets respectively. Due to depletion of the developed culture and organic content of the waste, gas production becomes decreased and then nearly zero at $22^{\text {th }}$ and $29^{\text {th }}$ days of the $1^{\text {st }}$ and $2^{\text {nd }}$ sets. But For the last two cases production is not completed within thirty days. Finally, $10 \mathrm{~kg}$ of food waste has been produced a total of $2.292,1.783,1.172$ and $0.962 \mathrm{~m}^{3}$ of biogas from the $1^{\text {st }}, 2^{\text {nd }}, 3^{\text {rd }}$ and $4^{\text {th }}$ sets respectively and the best waste/water ratio is 1:2. Temperature, particle size and $\mathrm{pH}$ are the main factors affecting microbial activity and then methane production. Of those, temperature is the most important factor. Low $\mathrm{pH}$ decrease's the biogas production by facilitating hydrolysis and acidogenesis reactions and makes bacteria's to utilize the waste more readily. Generally, production of biogas in Shoarobit is more feasible, and takes short time than in Debre Berhan town.
\end{abstract}

Keywords: Anaerobic Digestion, Compact Bio-Digester, Particle Size, PH, Temperature

\section{Introduction}

Due to scarcity of petroleum and coal it threatens supply of fuel throughout the world and problem of their combustion leads to research in different corners to get access of new sources of energy, like solar energy, different thermal and hydro sources of energy, wind energy and biogas [1, 2]. But, biogas is distinct from other renewable energies because it does have neither geographical limitation nor does it require advanced technology for producing energy, also it is very simple to use and apply [3, 4]. Biogas or methane yield is measured by the amount of methane that can be produced per unit of volatile solids contained in the feedstock after subjecting it to anaerobic digestion for a sufficient amount of time under a given temperature.

In recent times varied technological modifications and improvements have been introduced to diminish the costs for the production of biogas, to increase speed of fermentation for the gas producer bacteria's, to reduce size of the reactors, the use of starchy and sugary materials for the gas production, modification of the feeding materials for fermentation and the exit of the effluent for their better employment, as well as compaction of the equipment to produce gas in small places like back-yard, among others [5, $6]$.

One of the most common biogas sources is kitchen waste which has the highest calorific and nutritive value to microbes. However till now we have not been benefited from kitchen waste, because of ignorance of basic sciences - like output of work is dependent on energy available for doing that work. This fact can be seen in current practices of using low calorific inputs like cattle dung, distillery effluent, municipal solid waste or sewage in biogas plants, making methane generation highly inefficient. Anaerobic digestion is a promising method to treat the kitchen wastes. Factors like feedstock characteristics, design of reactors and operation conditions, moisture content, volatile solids, nutrient contents, particle size, biodegradability of the organic wastes affects the design and performance of anaerobic digestion [3, $4,7,8]$.

The biodegradability of a feed is indicated by biogas production or methane yield and percentage of solids (total solids or total volatile solids) that are destroyed in the anaerobic digestion $[9,10,11]$. The analysis of the compact 
biogas system developed in 2003, that uses starchy or sugary feedstock material, shows that bio mass generated from kitchen waste is 800 times more efficient than conventional biogas produced from manure [12, 13]. Although kitchen waste has the highest calorific and nutritive value to produce biogas, in most of Ethiopia towns and places, like Shoa-Robit and Debre Berhan, kitchen waste is disposed in landfill or discarded which causes the public health hazards and diseases like malaria, cholera, typhoid and it emits unpleasant odor and methane, which is a major greenhouse gas contributing to global warming. Inadequate management of wastes bears several adverse consequences. It not only leads to polluting surface and groundwater through leachate and further promotes the breeding of flies, mosquitoes, rats and other disease bearing vectors $[14,15]$.

In this study effort are made to produce bio gas from kitchen wastes of selected hotels and restaurants of Shoarobit town and Debre Berhan town in uniquely designed digesters. The objective of this study was to test the feasibility of biogas production from food waste in a uniquely designed bath digester and to compare biogas production from kitchen waste in the two towns. Some of the research benefits for the society are; Biogas uses as renewable energy source, reduces greenhouse gas emissions and mitigation of global warming, reduces dependency on imported fossil fuels and improves waste management and Sanitation.

\section{Methodology}

\subsection{Description of the Survey Area}

Shoa-Robit and Debre Berhan, the survey areas are developing towns in north Shoa- zone, Ethiopia. They are found at 130 and $225 \mathrm{~K}$. M from Addis Ababa, the capital city of Ethiopia and are located between $10^{\circ} 00^{\prime} \mathrm{N} 39^{\circ} 54^{\prime} \mathrm{E}$ and $9^{\circ} 41^{\prime} \mathrm{N} 39^{\circ} 32^{\prime} \mathrm{E}$ with an elevation of $1280 \mathrm{~m}$ and $2840 \mathrm{~m}$ above sea level respectively.

The climate of Shoa-Robit is characterized by warm temperature with unimodal rainy season. The average yearly minimum and maximum temperatures are $24^{\circ} \mathrm{C}$ and $35^{\circ} \mathrm{C}$. The climate of Debre Berhan is in between $0^{\circ} \mathrm{C}$ and $20^{\circ} \mathrm{C}$.

\subsection{Source of Kitchen Waste}

The waste used in this study was collected from the selected hotels and restaurants of Debre Berhan and Shoarobit town including cafeterias of Debre Berhan University and Shoa-Robit prison.

\subsection{Pre-Treatment of Feedstock}

Organic household waste primarily consists of kitchen waste, which can be divided into food leftovers and peelings or pieces of vegetables and fruits. The food leftovers consisted of rice, lentil, curry, vegetable (beans), potato chips, and pieces of meat with sauce and fish residue as shown in figure below. Orange and banana peelings were also merged into the food remains. Tooth picks and meat bones were frequently among the food waste and had to be removed.

All wastes were stored in closed buckets and used within a maximum of 4 days. In average $10 \mathrm{Kg}$ of dry waste was collected daily. They were cut up with a kitchen knife and then put them into the chopper to make smaller size and to attain a particle size of less than $1 \mathrm{~cm}$. In our study, the pre-treatment of food waste was applied for all type of wastes.

\subsubsection{Preparation of Inoculum}

Cow dung was used to make inoculums which were just one day old. $3 \mathrm{Kg}$ of cow dung were mixed with three litre of water. The Inoculum was fed into the digester through inlet pipe.

\subsubsection{Preparation of Slurry}

The required amount of water was added to the grinded waste to make slurry. To compare among various rations of kitchen wastes, dilution were 1:4 (Case-I), 1:3 (Case-II), 1:2 (Case-III), 1:1.5 (Case-IV) and 1:1 (Case-V). For the other analysis Case-(1:2) was used. Depending on the type of analysis samples were taken from the homogenized slurry or from the fresh waste for further analysis. All the research analysis has been done under batch system in which the slurry has been added once to the digester for whole duration of the process.

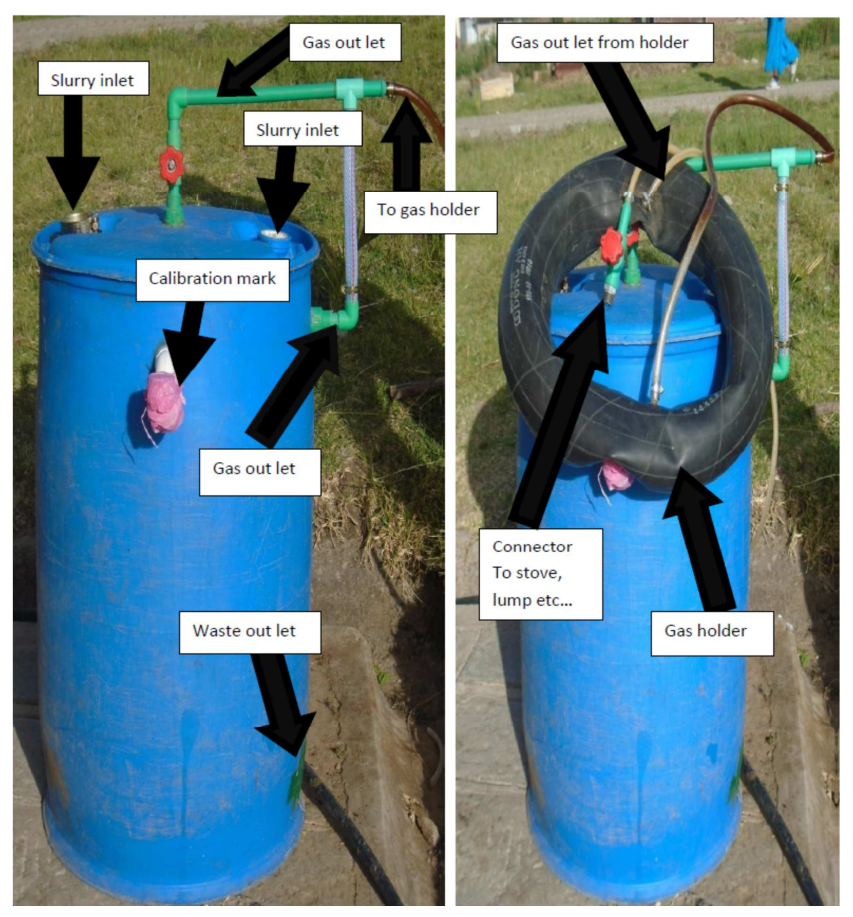

Figure 1. Compact bio-digester.

\subsection{Effect of Temperature}

To see the effect of temperature on biogas yield the biogas digester was put in three different average temperatures. In 
the first case, the digester was put in a place where the digester can get a sun light for $11 \mathrm{hr} /$ day (set-1), in the second case the digester was put in a place where the digester can get a sun light for $5 \mathrm{hr} /$ day (set-2) and in the third case the digester was put in a dark place where sun can't reach (set-3). The average temperatures of the three sets were 30.5, 25.5 and $21^{\circ}$. In case of Debre Berhan only set- 1 is studied with an average of $17^{\circ} \mathrm{C}$. The daily average temperature of each sets were measured by taking a measurement in two hours interval.

\subsection{Effect of $\mathrm{pH}$}

Daily $\mathrm{pH}$ of the slurry was measured using $\mathrm{pH}$ meter by taking very small amount of slurry through the out let of the digester and the respective daily produced biogas was measured.

\subsection{Analysis of GAS Produced Syringe Method}

Syringe method was used for the measurement of amount of methane and carbon dioxide in the produced gas. A syringe fitted with flexible tube and dilute sodium hydroxide $(\mathrm{NaOH})$ solution was used for carbon dioxide percentage estimation, since $\mathrm{NaOH}$ absorbs $\mathrm{CO}_{2}$ but does not absorbs methane.

\section{Result and Discussion}

\subsection{Effect of Temperature on Bio Gas Production}

It has been observed that the production of biogas is dependent upon the temperature. Fluctuations in temperature affect the activity of methane forming bacteria to a greater extent. The effect of temperature on the first stages of the digestion process (hydrolysis and acidogenesis) is not very significant. The second and third stages of decomposition can only be performed by certain specialized microorganisms (acetogenic and methanogenic bacteria) and these are much more sensitive towards temperature change.

The digester with an average temperature of approximately $30.5^{\circ} \mathrm{C}$ (set-1), the cycle has been easily completed in less than 15 day and the digester with an average temperature of $25.5^{\circ} \mathrm{C}$ (set-2) was approximately completed within 23 days. However, the digester with an average temperature of $21^{\circ} \mathrm{C}$ (set-3) and $17^{\circ} \mathrm{C}$ (digester in Debre Berhan) was not completed even in thirty days. Although, fluctuations in temperature may be advantage and disadvantage, an important characteristic of anaerobi bacteria is that their decay rate is very low in Debre Berhan at temperatures below $20^{\circ} \mathrm{C}$. In the Mesophilic range, the activity and growth of the bacteria decreases by one-half for each $10^{\circ} \mathrm{C}$ drop below $35^{\circ} \mathrm{C}$.

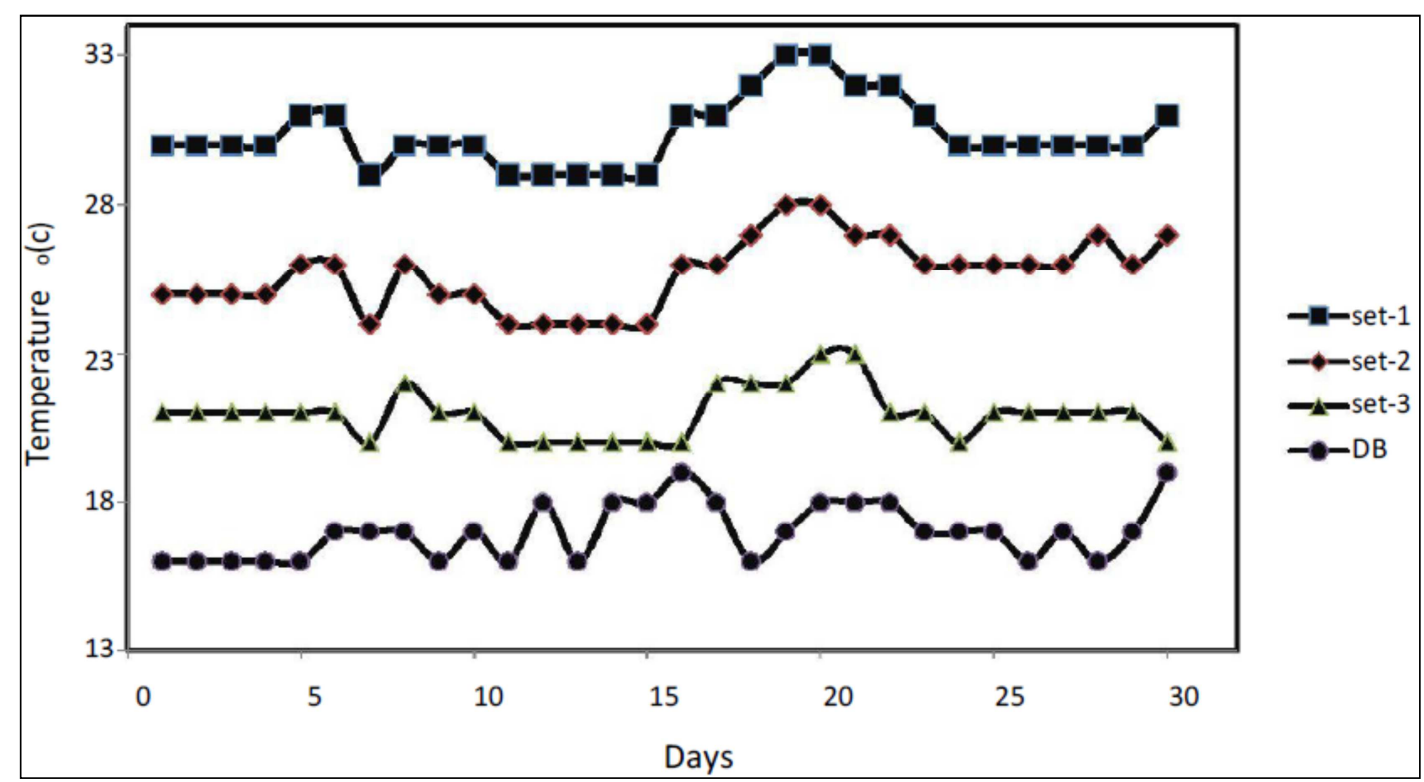

Figure 2. Variation of daily internal temperature of the different sets.

The synthesis of gas has been started from the first day of the slurry feeding inside the biogas chamber under set-I and set-II but we obtained methane fraction from third day. After three days production of gas gradually increased and picked to $0.360,0.260,0.150$ and $0.116 \mathrm{~m}^{3}$ at $9^{\text {th }}, 12^{\text {th }}$, $17^{\text {th }}$ and $23^{\text {th }}$ days of the $1^{\text {st }}, 2^{\text {nd }} 3^{\text {rd }}$ and Debre Berhan sets respectively and the gas production remained almost constant at the $9^{\text {th }}, 10^{\text {th }}$ and $11^{\text {th }}$ days for the $1^{\text {st }}$ set, at $12^{\text {th }}$, $13^{\text {th }}$ and $14^{\text {th }}$ days for the $2^{\text {nd }}$ set, at $17^{\text {th }}, 18$ th and $19^{\text {th }}$ days for the $3^{\text {rd }}$ set and at $23^{\text {th }}, 24^{\text {th }}$ and $25^{\text {th }}$ days for the digester in Debre Berhan town. Finally, due to the depletion of the developed culture and organic content of the waste, gas production becomes decreased and then nearly zero at $22^{\text {th }}$ and $29^{\text {th }}$ days of the $1^{\text {st }}$ and $2^{\text {nd }}$ sets respectively. For the third set and Debre Berhan case production of gas is not completed within thirty days. Generally, $10 \mathrm{~kg}$ of food waste has been produced a total of $2.292,1.783,1.172$ and $0.962 \mathrm{~m}^{3}$ of biogas from the $1^{\text {st }}, 2^{\text {nd }}, 3^{\text {rd }}$ and Debre Berhan sets respectively. This shows gas production is strongly temperature dependent. 


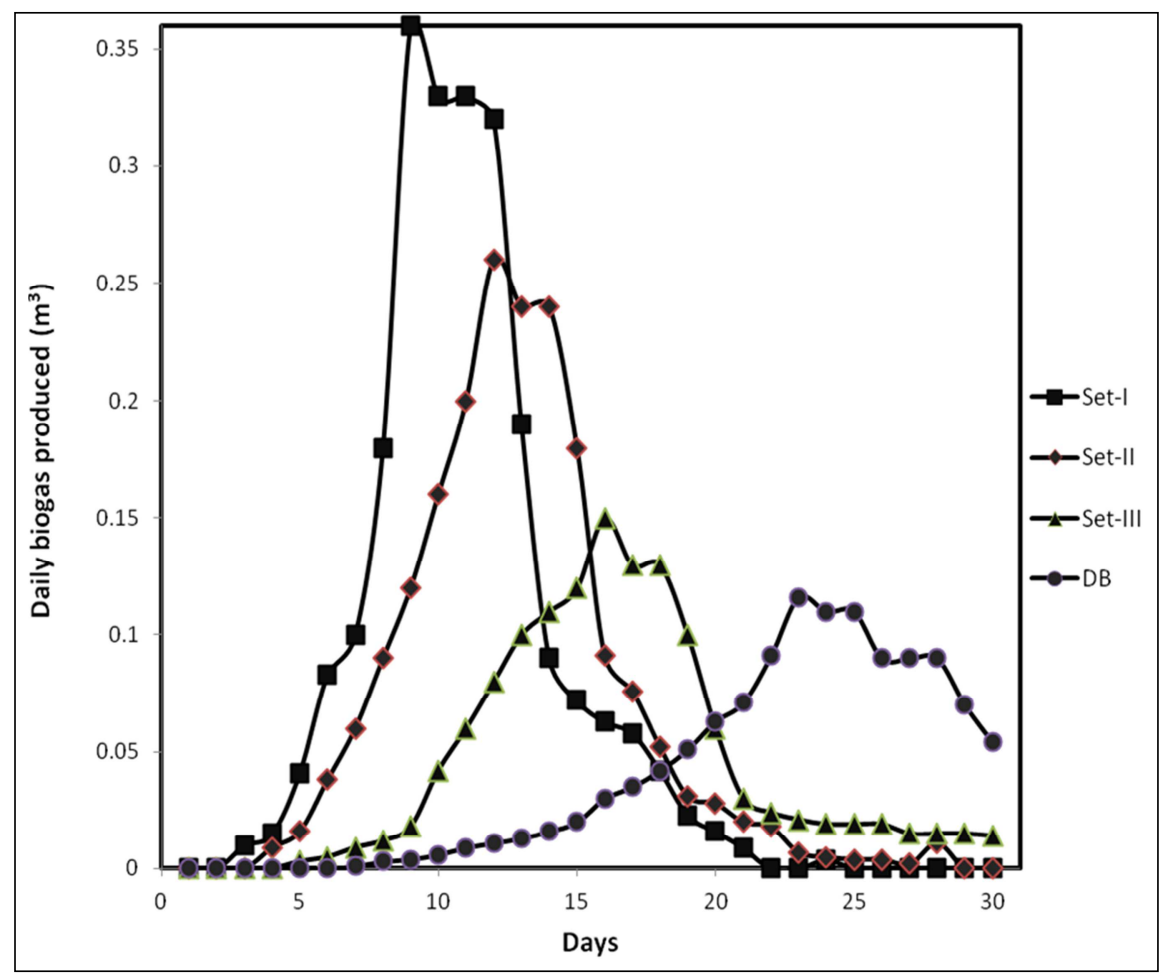

Figure 3. Daily gas production for the three different sets in Shoarobit and in Debre Berhan.

\subsection{Effect of $p H$}

The $\mathrm{pH}$ value of the digester content is an important indicator of the performance and the stability of an anaerobic digester. In a well-balanced anaerobic digestion process, almost all products of a metabolic stage are continuously converted into the next breaking down product without any significant accumulation of intermediary products such as different fatty acids which would cause a $\mathrm{pH}$ drop. Many aspects of the complex microbial metabolism are greatly influenced by $\mathrm{pH}$ variations in the digester.

\subsection{Quality of the Produces Gas}

The syringe - protocol method was used to test the quality of the gas. A syringe body fitted with dome flexible tube and dilute sodium hydroxide $(\mathrm{NaOH})$ solution was used to estimate carbon dioxide percentage. The $\mathrm{NaOH}$ solution inside the tube absorbs only carbon dioxide but not methane. The data recorded using this method shows, at the first three days of measurement, carbon dioxide represents more than $50 \%$ by volume, whereas, methane seems to be $19 \%$. Composition of $\mathrm{CO}_{2}$ gradually decreases and dropped to a value of $38 \%$ by volume for the last days of experiment. On the other hand, the percentage of methane sharply increases and peaked to the value of $62 \%$ by volume in last day. The result shows that the percentage of methane exceeded the percentage of carbon dioxide as the time passes and if there is favourable environment for the bacteria such as temperature and well developed culture.

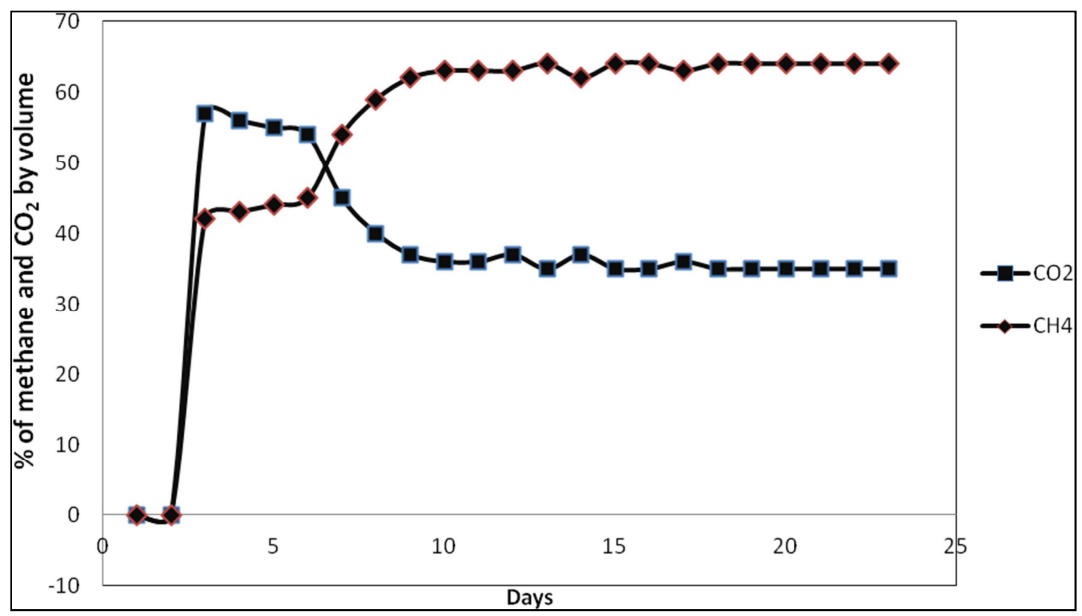

Figure 4. Percent of methane and carbon dioxide daily produced. 


\section{Conclusion}

The study shows that utilization of kitchen waste using a simple and compact digester for biogas production offers effective waste management and resource development solutions with positive measures for the economy and sustained energy security. This biogas digester is economical with initial investment cost of 870 birr and it is small in size which can be put at backyard of home in $4 \mathrm{~m}^{2}$ area. Using this simple and compact biogas digester, $10 \mathrm{~kg}$ of kitchen waste was produced $2.292 \mathrm{~m}^{3}$ of gas if there is ambient environment like optimum temperature conditions (greater than $26^{\circ} \mathrm{C}$ ), $\mathrm{pH}$ (6.8-7.7), percentage of total solids (greater than 12\%) and particle size of less than $1 \mathrm{~cm}$. By storing the 2-3 days' produced gas it will be equivalent to consumption of 1 days LPG gas. So, anaerobic digestion of kitchen waste using simple and compact digester is a more feasible proven technology and economical for hotels and households in urban areas. Finally, it is highly recommended that this simple and compact digester can be used in rural regions preferably using animal feeds.

\section{References}

[1] Levis, J. W. (2010). Assessment of the state of food waste treatment in the United States and Canada. Journal of Waste Management 30 (8-9): 1486-94.

[2] Ma, J., Doung, T. (2011). Enhanced biomethanation of kitchen waste by different pre treatment methods. Journal of Bioresource Technology 102: 592-599.

[3] Sans, C. (1995). Volatile Fatty Acids Production by Mesophilic Fermentation of Mechanically- Sorted Urban Organic waste in a Plug- Flow Reactor. Journal of Bioresource Technology 51: 89-96.

[4] Elefsiniotis, P., Wareham, G. D., (2006). Utilization Patterns of Volatile Fatty Acids in the Denitrification Reaction. Journal of Enzyme and Microbial Technology 41: 92-97.

[5] Parkin, G. F., Owen, W. F. (1986). Fundamentals of Anaerobic
Digestion of Waste water Sludge. Journal of Environmental Engineering 112 (5): 867-920.

[6] Liu, C. (2007). Prediction of methane yield at optimum $\mathrm{pH}$ for anaerobic digestion of organic fraction of municipal solid waste. Journal of Bioresource Technology 99: 882-888.

[7] Thomsen, A. B., Lissens, G., Baere, L., Verstraete, W., Ahring, B. (2004). Thermal wet oxidation improves anaerobic biodegradability of raw and digested bio-waste. Journal of Environmental Science and Technology 38: 3418-3424.

[8] Ralph, M., Dong, J. (2010). Environmental Microbiology Second. A John Wiley \& Sons, Inc., Publication.

[9] Mata-Alvarez, J., Mace, S., Llabres, P. (2000). Anaerobic digestion of organic solid wastes. An overview of research achievements and perspectives. Journal of Bioresource Technology 74: 3-16.

[10] Kumar, S., Gaikwad, S. A., Shekdar, A. K., Kshirsagar, P. K., Singh, R. N. (2004). Estimation method for national methane emission from solid waste landfills. Atmospheric Environment. 38: 3481-3487.

[11] Jantsch, T. G., Matttiason, B. (2004). An automated Spectrophotometry system for monitoring buffer capacity in anaerobic digestion processes. Water Research. 38: 36453650 .

[12] Thomsen, A. B., Lissens, G., Baere, L., Verstraete, W., Ahring, B. (2004). Thermal wet oxidation improves anaerobic biodegradability of raw and digested bio-waste. Environmental Science and Technology. 38: 3418-3424.

[13] Gebreegziabher, S. a et al., 2010. "Economic analysis of anaerobic digestion-A case of Green power biogas plant in The Netherlands". NJAS - Wageningen Journal of Life Sciences, 57 (2), pp. 109-115.

[14] 20. Lim, S.-J. et al., 2008. "Anaerobic organic acid production of food waste in once-a-day feeding and drawing-off bioreactor". Bioresource Technology, 99, pp. 7866- 7874.

[15] Distefano, Thomas D. Belenky, L. G., 2009. Life-Cycle Analysis of Energy and Greenhouse Gas Emissions from Anaerobic Biodegradation of Municipal Solid Waste”. Journal of Environmental Engineering, 135 (11), p. 1097. 